\title{
PROBLEMATIKA HUKUM PEMBAGIAN WARIS 2:1 DALAM PENDEKATAN TEORI QATH'I ZHANNI
}

\author{
Al - Robin \\ Mahasiswa Pasca Sarjana UIN Sunan Kalijaga Yogyakarta \\ Jl. Laksda Adisucipto, Sleman, Daerah Istimewa Yogyakarta \\ alrobin935@gmail.com
}

\section{Abstract :}

In inheritance law of Islam, the Qur'an has idealized and specified clearly that sons inherit twice that of daughters. Instead of legal practice some communities in Indonesia that the sons received the same parts with the daughters. Even dividing when the heir is still alive because their lack of understanding of the text qath'i zhani. Qath'i al-dalalah Islamic inheritance texts about the distribution of 2: 1 between sons and daughters, according to the ulama not absolutely necessary, as the opinion of Munawir Sjadazali. Thus it was stated by Mashdar Farid Mas'udin, that the qath' $i$ was only the principles of justice are conceived by the verses of the Islamic inheritance and not the provisions of section men who got twice that of women. But this kind of division has implications for the strength of law, if there is a dispute in the future then it is incapable to be accountable because distribution is outside of the provisions of the Qur'an and Law and also, this sort of thing would have implications for the impartial justice in Islamic inheritance law of the balance between the rights of the estate obtained by the obligations or burdens that must be borne or fulfilled among the heirs. Therefore, the sense of justice in Islamic inheritance law is not measured by the similarity degree between the heirs, but is determined based on the large-small burden or 
responsibility entrusted to them, in terms of generality state/human life.

Keyword : Legacy, Qath'i Zhanni, Justice.

\section{PENDAHULUAN}

Hukum kewarisan Islam merupakan salah satu persoalan penting dalam Islam, dan merupakan tiang di antara tiang-tiang hukum yang secara mendasar tercermin langsung dari teks-teks suci yang telah disepakati keberadaannya. ${ }^{1}$ Satu hal yang tidak dapat dipungkiri, keberadaan hukum kewarisan Islam dipresentasikan dalam teks-teks yang rinci, sistematis, konkrit, dan realistis. Kerincian pemaparan teks tentang kewarisan sampai beimplikasi pada keyakinan ulama tradisional bahwa hukum kewarisan Islam tidak dapat berubah dan menolak segala ide pembaharuan. Hal ini terlihat dari teks-teks kitab fikih klasik yang menyebutkan hukum kewarisan Islam dengan ilmu "faraidl". Kata faraidl merupakan jamak dari fa-ra-dla yang berarti ketentuan, sehingga ilmu faraidl diartikan dengan ilmu bagian yang pasti.

Kehadiran hukum kewarisan Islam merupakan salah satu bentuk perhatian Islam terhadap pemeliharaan harta peninggalan seorang muslim. Di samping itu, hukum kewarisan Islam merupakan relasi dari perintah al-Qur'an untuk tidak meninggalkan ahli waris (keturunan) dalam keadaan lemah. Rangkaian dan ketentuan yang ada dalam hukum kewarisan merupakan hukum aplikatif bukan teoritik. Pengalamannya merupakan wajib 'ain dan mempelajarinya merupakan kawajiban kolektif (fardlu kifayah).

Qur'an merupakan acuan utama hukum dan penentuan pembagian waris, sedangkan ketetapan tentang kewarisan yang diambil dari hadist Rasulullah saw. dan ijm' para ulama sangat

1 Abdul Ghofur Anshori, Filsafat Hukum Kewarisan Islam, Konsep Kewarisan Bilateral Hazairin, (Yogyakarta: UII Press, 2010), 15. 
sedikit. Dapat dikatakan bahwa dalam hukum dan syariat Islam sedikit sekali ayat al-Qur'an yang merinci suatu hukum secara detail dan rinci, kecuali hukum kewarisan ini. Hal demikian disebabkan kewarisan merupakan salah satu bentuk kepemilikan yang legal dan dibenarkan Allah SWT. di samping bahwa harta merupakan tongkat penegak kehidupan baik bagi individu maupun kelompok masyarakat.

Di zaman Jahiliyah, aturan pusaka orang Arab didasarkan atas nasab dan qarabah (hubungan darah dan kekeluargaan). ${ }^{2}$ Namun sebatas kepada anak laki-laki yang sudah dapat memanggul senjata untuk membela kehormatan keluarga dan dapat memperoleh harta rampasan perang. Mereka tidak memberikan pusaka, kepada para wanita dan anak-anak yang masih kecil. Hal ini terus berlaku sampai permulaan Islam, sehingga turun ayat yang menerangkan bahwa para lelaki memperoleh bagian (pusaka) dari harta peninggalan orang tua dan kerabat-kerabat terdekat, dan begitupun bagi perempuan ada hak bagian (pula) dari harta peninggalan kedua orang tua dan kerabatnya, baik harta itu sedikit ataupun banyak. (QS. An-Nisa' [4]:7). Dengan turunnya QS. An-Nisa' ayat 7, maka terputuslah adat jahiliyah yang tidak memberikan pusaka kepada para wanita dan anak-anak kecil. Kemudian ayat-ayat itu dijelaskan dalam surat an-Nisa' [4]: 11, 12 dan 176. Namun dengan semaking berkembangnya ilmu pengetahuan saat ini, banyak kalangan yang tau terhadap ketentuan al-Qur'an tentang pembagian harta waris. Dan banyak juga yang menggugat dan menganggap dalil ini bermakna zhanni, sehingga dapat diubah ketentuan besar perolehan ahli waris, terutama bagian anak laki-laki sama dengan bagian yang diterima oleh ahli waris anak perempuan, yaitu 1:1.

2 Teungku Muhammad Hasbi Ash-Shiddieqy, Figh Mawaris, Hukum Pembagian Warisan Menurut Syariat Islam,cet. ke-2, (Semarang: Pustaka Rizki Putra,2017), 2.

Sangaji Jurnal Pemikiran Syariah dan Hukum 
Terlepas dari alasan yang argumentatif dan filosofis yang dikemukakan, yang jelas upaya tersebut mencoba menjauhkan diri dari hukum-hukum Allah SWT. Hal tersebut sebagaimana yang dikemukakan oleh Mashdar Farid Mas'udin. Mashdar mengatakan bahwa yang qath'i itu hanyalah prinsip keadilan saja yang dikandung oleh ayat-ayat kewarisan Islam tersebut, bukan ketentuan bagian laki-laki yang mendapat dua kali lipat dari perempuan. ${ }^{3}$

Pendapat di atas berbeda dengan apa yang dikemukakan oleh Yusuf al-Qardawi. Al-Qardawi menegaskan, tidak boleh membuka pintu ijtihad dalam hukum yang telah ditetapkan berdasarkan dalil al-Qur'an yang sudah qath'i. Karena kewajiban pembagian harta warisan kepada anak laki-laki dua kali lebih besar dari anak perempuan itu mengutamakan dalil al-Qur'an yang sudah qath'i. ${ }^{4}$ Hukum yang sudah qath'i harus tetap dalam posisinya yang qath'i, begitu pula hukum yang zhanni. Menurut alQardawi, tidak boleh mengubah hukum atau nash yang qath'i menjadi nash yang zhanni atau mengubah hukum zhanni menjadi qath'i.

Berawal dari penafsiran yang berbeda inilah, sehingga menjadi problematika dalam masyarakat Islam tentang persoalan hukum pembagian waris yang didapatkan masing-masing ahli waris. Terutama bagian anak laki-laki dan bagian anak perempuan. Ada yang mengatakan bahwa bagian anak laki-laki sama dengan bagian dua anak perempuan, sesuai dengan yang telah ditetapkan dalam syariat Islam. Namun ada juga yang mengatakan bahwa, bagian 2:1 itu sudah tidak relevan atau tidak

3 Mashdar Farid Mas'ud, Hak-hak Reproduksi Perempuan: Dialog Figh Pemberdayaan, (Bandung: Mizan, 1997), 41.

${ }^{4}$ Fathurrahman Djamil, Filsafat Hukum Islam, cet. ke-1, (Jakarta: Logos Wacana Ilmu, 1997), 132-133. 
cocok lagi untuk diterapkan di zaman sekarang, karena itu adalah budaya orang Arab.

Tulisan ini berusaha mengkaji beberapa masalah seputar faktor penyebab terjadinya perbedaan pendapat tentang kekuatan hukum aturan waris dalam al-Qur'an dan implikasi penggunaan teori qath'i zhanni terhadap formula pembagian waris 2:1.

\section{GAMBARAN QATH'I ZHANNI}

Kata qath'i adalah mashdar dari qatha'a-yaqtha'u-qath'an yang berarti $^{5}$ abana-yabinu-ibanatan: memisahkan, menjelaskan. ${ }^{6}$ Kata qath'i juga berarti: decided (pasti, jelas), definite (tertentu), positive (meyakinkan), final, definitive (pasti, menyatukan). ${ }^{7}$ Term qath'i terkadang juga disinonimkan dengan dharuri, yaqini, absolut, dan mutlak. ${ }^{8}$ Sedangkan kata zhanni berasal dari kata zhanna-yazhunnuzhannun yang berarti syakk (samar) ${ }^{9}$ atau bererti pula yaqin yang bersandarkan pemikiran abstrak. ${ }^{10}$ Atau yang masih berupa asumsi, dugaan, anggapan, dan hipotesis. ${ }^{11}$ Term zhanni juga disinonimkan dengan kata nazhari, relatif dan nisbi. ${ }^{12}$

Berpangkal dari pengertian-pengertian di atas maka yang dimaksud dengan qath'i adalah petunjuk yang pasti dan jelas. Sedangkan zhanni adalah petunjuk yang masih berupa dugaan, asumsi, hipotesa atau masih samar, karenanya bisa memungkinkan timbulnya pengertian dan makna lain.

${ }^{5}$ Muhammad Abu Zahrah, Ushul Fiqh, (Jakarta: Pustaka Firdaus,1994), 188.

${ }^{6}$ Ibid., 237.

7 Ibid.

8 Abdul. Al-Wahhab Khallaf, 'Ilm Ushul al-Figh, (Kairo: Dar al-Qalam, 1978), 86.

${ }_{9}$ Muktar Yahya dan Facthurahman, Dasar-dasar Pembinaan Hukum Fiqih Islami, (Bandung: al-Ma'arif, 1993), 83.

${ }^{10}$ Ibid., h. 84.

${ }^{11}$ Nasrun Haroen, Ushul Fiqh, 1 (Jakarta: Logos, 1996), 81.

${ }^{12} \mathrm{Ibid} ., 82$.

Sangaji Jurnal Pemikiran Syariah dan Hukum 
Adapun pendapat al-Syatibi berkenaan dengan qath'i dan zhanni sebagaimana yang dikutip oleh Quraish Shihab, bahwa dalil syara' ada yang qath'i dan ada juga yang zhanni. Semua dalil yang terdapat di dalam al-Qur'an baik yang mujmal maupun yang terperinci adalah qath'i. Sedangkan sunnah dan ijma' yang keduanya adalah zhanni bisa menjadi qath'i al-dalalah bisa juga menjadi zhanni. Adapun qiyas semuanya zhanni.13 Menurut alSyartibi, jika dalil itu qath'i, maka tidak ada keraguan untuk menerimanya dan menjadikannya sebagai hujjah, landasan hukum. Seperti dalil tentang: wajib bersuci dari hadas, kewajiban shalat, zakat, puasa, haji, amar ma'ruf, nahy munkar, persatuan umat, menegakkan keadilan dan sebagainya. Dan jika dalil itu zhanni, maka sebelum mengunakannya sebagai hujjah harus dikembalikan kepada ashl yang qath'i terlebih dahulu. Apakah terdapat pada ashl atau tidak.14

Jika dikaitkan dengan nash (dalil syara': al-Qur'an maupun sunnah). Menurut Muhammad Hashim Komali, nash qaht'i adalah nash yang jelas dan tertentu yang hanya memiliki satu makna dan tidak terbuka untuk makna lain, atau hanya memiliki satu penafsiran dan tidak terbuka untuk penafsiran lain.15 Dan juga yang dimaksud dengan nash atau teks yang qath'i yakni kata atau kalimat yang mangendung arti yang jelas sekali, sehingga tidak mungkin ditafsirkan dan diartikan lain dari yang tersebut dalam teks. Seperti nash-nash yang berkaitan dengan mawarits, hudud,16 juga pada nash-nash yang berkaitan dengan masalah 'aqidah.

${ }^{13}$ M. Quraish Shihab, Membumikan al-Qur'an, (Bandung: Mizan,1994), 91.

14 Untuk lebih jelasnya tentang pendapat-pendapat Abdul, lihat Muhammad Rasyid Ridha, dalam Tafsir al-Manar, (Cairo: al-Manar,1367 H), 261.

15 Muhammad Hashim Komali, Principles of Islamic Jurisprudence. Diterjemahkan oleh Noorhaidi dengan judul: "Prinsip dan Teori-Teori Hukum Islam", cet. ke -1, (Yogyakarta: Pustaka Pelajar, 1996), 26.

${ }^{16}$ Lihat Muhammad Abu Zahrah, 136. 
Karena petunjuk dan dalalah-nya jelas, maka wajiblah bagi kita melaksanakannnya atau menerima apa adanya.

Sedangkan yang dimaksud dengan teks atau nash-nash alQur'an yang zhanni yakni kata atau kalimat yang menunjukkan arti atau memungkinkan pengertian lebih dari satu, masih mungkin ditafsirkan oleh orang yang berbeda dengan makna yang berbeda.17 Dari sinilah para ulama ushul menyatakan bahwa pelung ijtihad masih terbuka. Sebagaimana contoh ayat berikut ini;

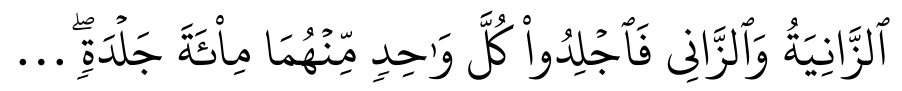

Terjemahannya:

Perempuan yang berzina dan laki-laki yang berzina, Maka deralah tiap-tiap seorang dari keduanya seratus kali dera, (QS. An-Nur: 2). ${ }^{18}$

Ayat juga secara pasti menunjukkan bahwa had zina adalah ratusan kali deraan, tidak lebih dan tidak kurang. Demikian juga setiap nash yang menunjukkan bagian dalam harta warisan yang telah ditentukan jumlahnya atau hukuman tertentu atau nishab yang tertentu.

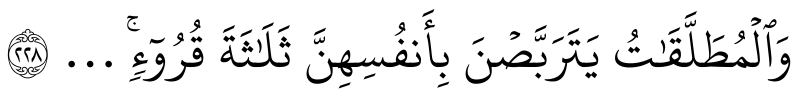

Terjemahannya:

Wanita-wanita yang ditalak handaklah menahan diri (menunggu) tiga kali quru', (QS. Al-Baqarah: 228). ${ }^{19}$

Lafazh "Quru'i" dalam bahasa Arab merupakan lafaz musytarak antara dua makna. Ia diartikan "suci", dan menurut bahasa ia juga diartikan "haidh". Nash menunjukkan bahwa

${ }^{17}$ Lihat al-Syatibi, al-Muwafaqat, jilid III, (Cairo: Dar al-Fikr,t,th), 99.

18 Departemen Agama RI, Al-Qur'an dan Terjemahannya, (Bogor: PT. Sygma Examedia Arkanleema. 2007), 350.

${ }^{19}$ Departemen Agama, QS.2:228, 36.

Sangaji Jurnal Pemikiran Syariah dan Hukum 
wanita-wanita yang ditalak hendaklah menahan diri selama tiga kali quru'i. oleh karena itu, maka ada kemungkinan bahwa yang dimaksudkan adalah tiga kali haidh. Jadi lafazh ini tidaklah qath'i dalalah-nya terhadap salah satu dari dua makna itu. Oleh karena inilah, maka para mijtahid berselisih pendapat mengenai masa tunggu wanita yang ditalak: tiga kali haidh ataukah tiga kali suci.

\section{FAKTOR PENYEBAB TERJADINYA PERBEDAAN PENDAPAT TENTANG KEKUATAN HUKUM ATURAN WARIS DALAM AL-QUR'AN}

1. Konteks Sosial-Historis Ayat

Pada zaman Jahiliah orang-orang Arab adalah bangsa yang gemar mengembara dan berperang dan kehidupannya bergantung dari hasil perniagaan rempah-rempah serta hasil jarahan dan rampasan perang dari bangsa-bangsa yang mereka taklukkan. ${ }^{20}$ Mereka beranggapan bahwa kaum laki-laki yang sudah dewasa saja yang mampu dan memiliki kekuatan dan kekuasaan dalam memelihara harta kekayaan mereka. Anggapan semacam di atas berlaku pula dalam hal pembagian harta warisan. Itulah sebabnya mereka, saat itu memberikan harta warisan kepada kaum laki-laki, tidak kepada kaum perempuan; kepada orang-orang yang sudah dewasa, tidak kepada anak-anak; dan kepada orang-orang yang mempunyai perjanjian prasetia, juga kepada orang-orang diadopsi. Menurut mereka, anak-anak yang belum dewasa dan kaum perempuan termasuk keluarga yang belum atau tidak pantas menjadi ahli waris. Bahkan sebagian mereka beranggapan bahwa janda perempuan dari orang yang meninggal termasuk sebagai

20 Suparman Usman dan Yusuf Somawinata, "Fiqh Mawaris", dalam Hukum Kewarisan Islam, (Jakarta: Gaya Media Pratama, 2002), 2. 
ujud harta warisan yang dapat diwariskan kepada dan diwarisi oleh para ahli waris suaminya. ${ }^{21}$

Hal ini terus berlaku sampai permulaan Islam, sehingga turun ayat yang menerangkan bahwa para lelaki memperoleh bagian (pusaka) dari harta peniggalan orang tua dan kerabatkerabat terdekat, dan begitupun bagi perempuan ada hak bagian (pula) dari harta peninggalan kedua orang tua dan kerabatnya, baik harta itu sedikit ataupun banyak menurut bahagian yang telah ditetapkan (QS. An-Nisa' [4]:7).

Dengan turunnya ayat di atas, terhapuslah adat Jahiliah yang tidak memberikan warisan kepada perempuan dan anakanak kecil.22 Namun firman Allah tentang pembagian harta waris tidak sampai di situ. Karena makna ayat ini masih umum atau zhanni dan belum jelas pembagiannya. Di akhir ayat ini Allah berfirman, نصيبا مفروضا "Menurut pembagian yang telah ditetapkan". Artinya, adalah Allah telah menetapkan pembagian harta warisan. Namun sebelumnya belum ada ayat yang menjelaskan pembagian harta warisan, itu berarti bahwa Allah akan menjelaskan kembali dengan ayat-ayat berikutnya tentang pembagian harta waris. Sehingga Rasulullah saw. sendiripun tidak berani untuk menetukan bagian-bagian ahli waris. Sebagaimana telah dijelaskan dalam riwayat berikut ini;

Diriwayatkan oleh Ahmad, Abu Dawud, at-Tirmizi, dan alHakim, yang bersumber dari Jabir, menukilkan bahwa istri Sa'd bin Rabi' menhadap Rasulullah saw. dan berkata: "Ya Rasulullah, kedua putri ini anak Sa'd bin Rabi' yang menyertai tuan dalam pereng Uhud dan ia telah gugur sebagai Syahid. Paman kedua anak ini mengabil harta bendanya, dan tidak meninggalkan

${ }^{21}$ Ibid., 3.

22 Asrizal, "Peletakan Dasar-dasar Hukum Kewarisan Islam (Tinjau Historis atas Hukum Waris Pra dan Awal Islam)," dalam al-Ahwal Jurnal Hukum Keluarga Islam, Fakultas Syari'ah dan Hukum UIN Sunan Kalijaga, Vol 9, No.1, Juni 2016, 128.

Sangaji Jurnal Pemikiran Syariah dan Hukum 
sedikitpun, sedangkan kedua anak ini sukar mendapatkan jodoh kalau tidak berharta. "Rasulullah saw. bersabda: "Allah akan memutuskan persoalan tersebut.23 "Maka turunlah ayat hukum pembagian waris yakni QS. An-Nisa': 11, 12, dan 176 sebagai berikut;

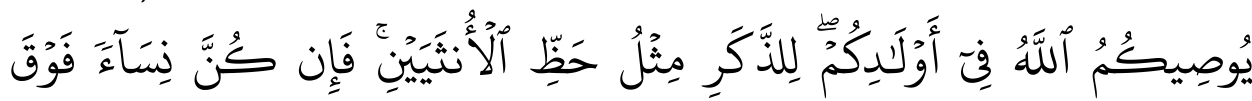

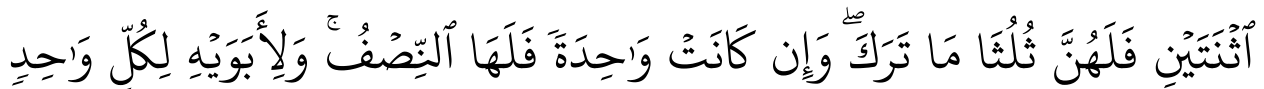

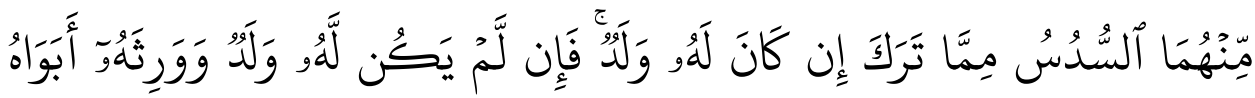

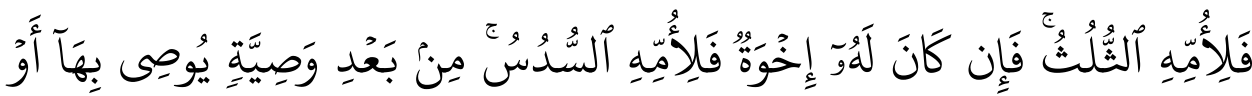

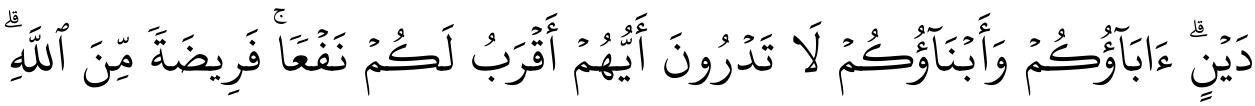

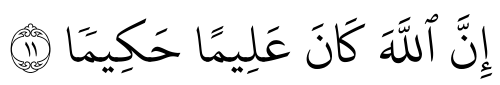

Terjemahannya:

Allah mensyari'atkan bagimu tentang (pembagian pusaka untuk) anak-anakmu. Yaitu: bahagian seorang anak lelaki sama dengan bagahian dua orang anak perempuan; dan jika anak itu semuanya perempuan lebih dari dua, Maka bagi mereka dua pertiga dari harta yang ditinggalkan; jika anak perempuan itu seorang saja, Maka ia memperoleh separo harta. Dan untuk dua orang ibubapak, bagi masing-masingnya seperenam dari harta yang ditinggalkan, jika yang meninggal itu mempunyai anak; jika orang yang meninggal tidak mempunyai anak dan ia diwarisi oleh ibu-bapanya (saja), Maka ibunya mendapat sepertiga; jika yang meninggal itu mempunyai beberapa saudara, Maka ibunya mendapat seperenam. (Pembagian-pembagian tersebut di atas) sesudah dipenuhi wasiat yang ia buat atau (dan) sesudah dibayar hutangnya. (Tentang) orang tuamu dan anak-anakmu, kamu tidak

23 Saleh dan Dahlan, Asbabun Nuzul, Latar Belakang Historis Turunnya Ayat-ayat al-Qur'an, cet. ke-10, (Bandung: Diponegoro, 2000), hlm. 130. 
mengetahui siapa di antara mereka yang lebih dekat (banyak) manfaatnya bagimu. Ini adalah ketetapan dari Allah. Sesungguhnya Allah Maha mengetahui lagi Maha Bijaksana. ${ }^{24}$ (QS. An-Nisa':11).

Firman Allah SWT, يو صيكم اله فى أولدكم للأكر منل حظ الأنثين "Allah mensyariatkan bagi kalian tentang pembagian pusaka untuk anak-anak kalian. Yaitu: Bagian seorang anak laki-lakisama dengan bagian dua orang anak perempuan." Yaitu Allah SWT memerintahkan kepada kalian untuk berlaku adil terhadap mereka. Karena sesungguhnya dahulu orang-orang Jahiliyah menjadikan semua harta warisan hanya untuk ahli waris laki-laki saja, tidak untuk ahli waris perempuan. Maka Allah SWT memerintahkan agar menyamaratakan di antara mereka (para ahli waris) dalam pokok harta warisan, namun Allah SWT membedakan bagian antara dua kelompok dimana Allah menjadikan bagian lelaki sama dengan bagian dua perempuan. Itu dikarekan laki-laki membutuhkan biaya nafkah dan beban yang ditanggung, letih dalam menjalankan perdagangan dan pertanian, mencari penghasilan, dan menanggung kesulitan. Maka sangatlah pantas jika dia diberi dua kali lipat dari apa yang terima oleh kaum perempuan. ${ }^{25}$

Dalam Surah An-Nisa' ayat 12 disebutkan dalam terjemahannya:

"Dan bagimu (suami-suami) seperdua dari harta yang ditinggalkan oleh isteri-isterimu, jika mereka tidak mempunyai anak. Jika Isteri-isterimu itu mempunyai anak, Maka kamu mendapat seperempat dari harta yang ditinggalkannya sesudah dipenuhi wasiat yang mereka buat

24 Departemen Agama RI, Al-Qur'an dan Terjemahannya, (Bogor: PT. Sygma Examedia Arkanleema. 2007), hlm. 78.

25 Syaikh Ahmad Syakir, Mukhtashar Tafsir Imam Ibnu Katsir, Jilid ke-2, terj. Suharla dan Suratman, (Jakarta: Darus Sunnah, 2014), 33.

Sangaji Jurnal Pemikiran Syariah dan Hukum 
atau (dan) seduah dibayar hutangnya. Para isteri memperoleh seperempat harta yang kamu tinggalkan jika kamu tidak mempunyai anak. Jika kamu mempunyai anak, Maka para isteri memperoleh seperdelapan dari harta yang kamu tinggalkan sesudah dipenuhi wasiat yang kamu buat atau (dan) sesudah dibayar hutang-hutangmu. Jika seseorang mati, baik laki-laki maupun perempuan yang tidak meninggalkan ayah dan tidak meninggalkan anak, tetapi mempunyai seorang saudara laki-laki (seibu saja) atau seorang saudara perempuan (seibu saja), Maka bagi masing-masing dari kedua jenis saudara itu seperenam harta. Tetapi jika Saudarasaudara seibu itu lebih dari seorang, Maka mereka bersekutu dalam yang sepertiga itu, sesudah dipenuhi wasiat yang dibuat olehnya atau sesudah dibayar hutangnya dengan tidak memberi mudharat (kepada ahli waris). (Allah menetapkan yang demikian itu sebagai) syari'at yang benar-benar dari Allah, dan Allah Maha mengetahui lagi Maha Penyantun." (QS. An-Nisa': 12).

Firman Allah SWT, ولكم نصف ماترك أزوجكم "Dan bagimu (suamisuami)seperdua dari harta yang ditinggalkan oleh istri-istrimu". Dua ayat di atas ditunjukkan bagi suami. Adapun yang dimaksud dengan anak di sini yaitu anak kandungnya, cucunya, dan terus generasi selanjutnya, baik seorang laki-laki maupun seorang perempuan. Para ulama sepakat bahwa suami mendapat $1 / 2$ harta tanpa kehadiran anak ataupun cucu. Jika ada anak, maka ia mendapatkan $1 / 4$. Seorang istri mendapatkan $1 / 4$ jika tidak ada anak, dan $1 / 8$ jika ada anak. ${ }^{26}$

Ulama sepakat bahwa sama hukumnya baik istri itu satu, dua, tiga dan empat, mereka berserikat dengan $1 / 4$ tadi jika tidak

${ }^{26}$ Imam al-Qurthubi, Tafsir al-Qurthubi, terj. Ahmad Rijal Kadir, Jidil ke5, (Jakarta: Pustaka Azzam, 2008), hlm. 186. 
ada anak dan berserikat dengan 1/8 jika ada anak, karena Allah SWT tidak menbedakan hukum-hukum atas mereka sebagaimana Allah membedakan hukum dengan kehadiran seorang anak wanita dengan adanya saudara perempuan dan hukum lebih daripada itu. ${ }^{27}$

Dan firman Allah SWT, وإن كان رجل يورث كلة أو امرأة "Jika seorang mati, baik laki-laki maupun perempuan secara kalalah (yang tidak meninggalkan ayah dan tidak meninggalkan anak)." Kalalah adalah mashdar, berasal dari pertautan nasab. Disebutkan pula iklik yaitu tempat beredarnya bulan. Bisa berarti menutup kepala, serban yang menutupi kepala sehingga jika seseorang mati tanpa meninggalkan anak laki-laki maupun ayah maka kalalah yang mewarisinya. Ini merupakan pendapat Abu Bakar As-Shiddiq, Umar, Ali dan jumhur ulama. ${ }^{28}$

Setelah sebelumnya dijelaskan hak masing-masing dalam keadaan mereka sendiri, kini dijelaskannya bila mereka tidak sendirian yaitu; jika saudara perempuan yang mewarisi itu dua orang, yang seayah, baik keduanya sekandung ataupun tidak, maka bagi keduanya dua pertiga dari harta yang ditinggalkan oleh yang meninggal. Dan jika mereka, yakni ahli waris itu, terdiri dari saudara-saudara yang mencakup laki-laki dan perempuan, lebih dari dua orang, maka bagian seorang saudara laki-laki sebanyak bagian dua orang saudara perempuan. Allah sendiri menerangkan hukum-hukum waris ini, kepada kamu, tidak menyerahkan kepada selain-Nya supaya kamu tidak sesat karena kalau diserahkan kepada yang lain kamu dapat keliru dan sesat sebab nalar tidak mampu menjangkau segala sesuatu. Pengetahuan

${ }^{27}$ Ibid., h. 187.

${ }^{28}$ Ibid.,

Sangaji Jurnal Pemikiran Syariah dan Hukum 
manusia pun sangat terbatas sedang Allah Maha Mengetahui segala sesuatu. ${ }^{29}$

Namun banyak yang mengklaim kandungan ayat kewarisan di atas dengan alasan bahwa ayat-ayat ini hanya berlaku untuk masyarakat Arab pada waktu itu. Sebagaimana Sjadzali menyatakan bahwa kasus yang kebanyakan terjadi pada orang tua di Indonesia memiliki kebiasaan untuk mengutamakan kepentingan anak laki-laki dari pada anak perempuan. Anak lakilaki sering menghabiskan biaya hidup terutama sekolah. Menurutnya apabila dalam kenyataan semacam ini laki-laki tetap mendapatkan bagian waris 2:1, tentu hal ini mencerminkan ketidakadilan. Sjdazali mengatakan bahwa pada realitas sekarang, juga telah membudaya penyimpangan seraca tidak langsung atas ketentuan al-Qur'an dan hadis Nabi saw. Banyak yang mengambil tindakan sendiri, yaitu membagikan kekayaan kepada anakanaknya semasa mereka masih hidup dengan pembagian untuk masing-masing mendapat bagian yang sama besarnya tanpa membedakan jenis kelamin masing-masing yang dikategorikan sebagai hibah. Pada waktu mereka meninggal, maka kekayaan yang harus dibagi sudah tidak ada. ${ }^{30}$

Pemikiran Sjdazali tersebut, terbanttahkan oleh pemikiran Yusuf al-Qardawi. Al-Qardawi menegaskan, tidak boleh membuka pintu ijtihad dalam hukum yang telah ditetapkan berdasarkan dalil al-Qur'an yang sudah qath'i. Karena kewajiban pembagian harta warisan kepada anak laki-laki dua kali lebih besar dari anak perempuan itu menggunakan dalil al-Qur'an yang sudah qath'i. ${ }^{31}$ 2016), hlm. 841.

${ }^{29}$ Quraish Shihab, Tafsir al-Mishbah, Jilid ke-2 (Jakarta: Lenteran Hati,

${ }^{30}$ Munawir Sjdazali, Reaktualisasi Ajaran Islam, dalam Iqbal Abdurrauf Saimima (ad.), Polemik Reaktualisasi Ajaran Islam, (Jakarta: Pustaka Panjimas, 1998), hlm. 2.

${ }^{31}$ Fathurrahman Djimil, Filsafat Hukum Islam, cet. ke-1, (Jakarta: Logos Wacana Ilmu, 1997), hlm. 132-136. 
Hukum yang sudah qath'i harus tetap dalam posisinya yang qath'i, begitu pula hukum yang zhanni. Menurut al-Qardawi, tidak boleh menggubah hukum atau nash yang sudah qath'i menjadi nash yang zhanni atau menggubah hukum yang zhanni menjadi qath'i.

Al-Qardawi menegaskan, ijtihad bukan berarti upaya memberikan legitimasi terhadap realita menurut apa adanya, kamudia menarik keluar nash-nash dari ruang lingkup pengertiannya guna mendukung realita, karena itu, umat Islam dilarang untuk menjadi legitimator realita dan mencari-cari alasan untuk membenarkan realita itu dengan meninggalkan dalil-dalil syara' secara tekstual yang demikian ini menurut al-Qardawi jelas tidak dapat diterima.

Istilah qath'i zhanni masing-masing terdiri atas dua bagian, yaitu yang menyangkut al-wurud (kebenaran sumber) dan addalalah (kedudukan makna). Tidak terdapat perbedaan pendapat dikalangan umat Islam menyangkut kebenaran sumber al-Qur'an. Semua sepakat dan meyakini bahwa redaksi ayat-ayat al-Qur'an yang terhimpun dalam mushaf dan dibaca kaum muslimin diseluruh penjuruh dunia adalah sama tanpa sedikit perbedaan dengan yang diterima Nabi Muhammad saw dari Allah melalui malaikat Jibril. ${ }^{32}$

Al-Qur'an jelas qath'i al-wurud. Hakikatnya merupakan salah satu dari apa yang dikenal dengan istilah ma'lum min al din bi al dharurah (sesuatu yang sangat sudah jelas, aksomatik, dalam ajaran agama). Tidak ada perbedaan pendapat dalam hal ini, bahkan diyakini bahwa hal ini telah memasuki lapangan teologi, artinya pengingkaran qath'i al-wurudnya al-Qur'an akan membawa sejumlah konsekuensi teologis. Namun demikian, dari sisi ad-dalalah, ayat al-Qur'an ada yang qath'i dan ada pula yang

${ }^{32}$ M. Quraish Shihab, Membumikan al-Qur'an, Fungsi dan Peran Wahyu dalam Kehidupan Masyarakat, (Bandung: Mizan, 1999), hlm. 137.

Sangaji Jurnal Pemikiran Syariah dan Hukum 
zhanni, yang menjadi persoalannya adalah yang menyangkut kandungan makna redaksi ayat-ayat al-Qur'an ini. ${ }^{33}$

Nash atau ayat yang bersifat qath'i adalah lafal-lafal yang mengandung pengertian tunggal dan tidak bisa dipahami makna lain darinya. Adapun menurut definisi Abdul Wahhab Kallaf dalil qath'i ialah suatu teks yang menunjukkan pada makna tertentu yang dapat dipahami darinya, tidak ada kemungkinan untuk dita'wilkan, dan tidak ada peluang untuk memahami makna selain dari makna tekstualnya. ${ }^{34}$ Dalil-dalil qath'i dapat dipahami begitu saja dan penolakan terhadapnya berarti bentuk kekufuran. Misalnya, masalah akidah, seperti keyakinan terhadap surga dan neraka, serta yaumul hisab, adalah masalah-masalah agama yang tidak dapat dibantah lagi kepastiannya sehingga kita tidak punya alasan untuk tidak menyakininya.

Dalam memahami teori qath'i zhanni dari segi dalalahnya. Misalnya dalam memahami nash-nash hukum kewarisan Islam tentang bagian anak laki-laki sama dengan dua bagian anak perempuan. Sebagaimana Mashdar Farid Mas'udin mengatakan bahwa yang qath'i itu hanyalah tujuan dan prinsip keadilan saja yang dikandung oleh ayat-ayat kewarisan Islam tersebut, bukan ketentuan bagian 2:1 antara laki-laki dan perempuan. ${ }^{35}$

Dari sisi ad-dalalah (interpretasi), jika suatu ayat al-Qur'an atau teks al-Hadis hanya mengandung makna yang jelas dan tidak membuka kemungkinan interpretasi lain, ia disebut sebagai teks yang qath'i ad-dalalah. Wahbah al Zuhaily mengatakan qath'i addalalah adalah lafaz yang terdapat dalam al-Qur'an yang dapat dipahami dengan jelas dan mengandung makna tunggal. ${ }^{36}$ Nash-

33 Ibid.,

${ }^{34}$ Abdul Wahhab Kallaf, Ilmu Ushul Fiqh, cek. Ke-1, (Semarang: Dina Utama, 1994), hlm. 38.

${ }^{35}$ Mashdar Farid Mas'ud, Hak-hak Reproduksi Perempuan, h. 41.

${ }^{36}$ Wahbah al-Zuhaily, Ushul Fikih al-Islami, (Beirut: Dar al-Fikr, 2001), hlm. 441 . 
nash dalam al-Qur'an maupun Hadis yang dikategorikan kepada qath'i ad-dalalah adalah lafaz yang susunan kata-katanya menyebutkan angka, jumlah, bilangan tertentu, sifat atau nama dan jenis. Misalnya, misalnya tentang pembagian harta waris. Hudud, kaffarat, dan lain-lain. ${ }^{37}$

Dalam hukum kewarisan, Allah SWT telah menjelaskannya rincian pembagiannya dengan meyebutkan angka, jumlah, dan penuh dengan ketegasan. Sebagaimana disebutkan dalam QS. AnNisa' ayat 11, tentang bagian anak laki-laki dan perempuan. Di dalam ayat 11 ini, diawali dengan firman Allah SWT, يوصيكم اله "Allah mensyariatkan (mewajibkan) bagimu," adalah, "Allah mensyariatkan kepada kalian, فى أولد كم للذكر منل حظ الأنثيين" tentang (pembagian pusaka untuk) anak-anakmu. Yaitu: bagian seorang anak laki-laki sama dengan bagian dua orang anak perempaun." 38 Allah berfirman, 'Allah mensyariatkan kepada kalian jika salah seorang di antara kalian meninggal dunia dengan meninggalkan anak laki-laki dan perempaun, maka semua anak laki-laki dan perempuan berhak atas harta warisan. Bagi laki-laki sama dengan bagian dua anak perempuan.'

Akhir ayat 11, Allah SWT menegaskan فر يضة "Ini adalah ketetapan." Lafaz ini di-nashab sebagai mashdar penguat, sehingga maknanya يوصيكمyaitu ditetapka atas kalian. ${ }^{39}$ Seandainya ukuran bagian dan wasiat ditentukan dengan usaha keras, disebabkan mereka termasuk memiliki harta benda. Jika demikian maka perintahnya gugur, dimana Allah SWT menjelaskan bahwa seseorang tidak melakukan ijtihad dalam penentuan warisan bahkan Allah SWT menjelaskan bagian-bagiannya secara syar'i.

${ }^{37}$ Ibid.,

38 Abu Ja'far Muhammad bin Jarir Ath-Thabi, Tafsir Ath-Thabari, terj. Akhmad Affandi, Jilid ke-6 (Jakarta: Pustaka Azzam, 2008), hlm. 532.

${ }^{39}$ Imam al-Qurthubi, Tafsir al-Qurthubi, terj. Ahmat Rijali Kadir, Jilid ke-5 (Jakarta: Pustaka Azzam, 2008), hlm. 185.

Sangaji Jurnal Pemikiran Syariah dan Hukum 
Kemudian Allah SWT berfirman إن الله كان عليما حكيما "Sesungguhnya Allah Maha Mengetahui", dalam pembagian warisan. حكيم "Maha Bijaksana", maksudnya membagi dengan hikmah dan menjelaskan kepada ahli warisnya. ${ }^{40}$

Az-Zujaj sebagaimana dikutip oleh al-Qurthubi, ia berkata, yang dimaksud Maha Mengetahui adalah mengetahui segala sesuatu sebelum diciptakan. Maha Bijaksana dalam segala sesuatu yang Dia takdirkan dan sesuatu yang telah terjadi. ${ }^{41}$ Di ujung ayat 176, sebagaimana ditafsirkan oleh Abu Ja'far Allah SWT berfirman “يllah menerangkan (hukum ini) kepadamu, supaya kamu tidak sesat. Masudnya adalah, Allah telah menjelaskan kepadamu menegnai pembagian hukum warisan dan hukum kalalah, serta bagaimana ketentuan-ketentuannya terhadap mereka. 42 أن تضلو "Supaya kamu tidak sesat," maksudnya adalah agar kamu tidak tersesat dalam perkara kewarisan dan pembagiannya. Artinya, agar kamu tidak menyalahgunakan hak tersebut dan melakukan kesalahan dalam menetapkan pembagian hukum warisan itu, hingga membuatmu kehilangan petunjuk jalan menuju kebenaran. ${ }^{43}$

Demikianlah penjelasan ke-qath'i-an ayat al-Qur'an tentang pembagian harta waris yang telah disebutkan oleh Allah SWT melalui QS. An-Nisa' ayat 11, 12, dan 176. Dalam ayat ini telah di sebutkan oleh Allah tentang bagian masing-masing ahli waris, sehingga tidak perlu lagi ijtihad untuk dijelaskan atau di-takwil-kan dengan makna lain, karena esensi dari ijtihad itu adalah menjelaskan suatu produk hukum yang masih samar atau zhanni.

${ }^{40}$ Ibid., h. 186.

${ }^{41}$ Ibid.,

${ }^{42}$ Abu Ja'far Muhammad bin Jarir Ath-Thabi, Tafsir Ath-Thabari, h. 215.

${ }^{43}$ Ibid., 


\section{Implikasi Pengunaan Teori Qath'i Zhanni Terhadap Hukum Pembagian Harta Waris 2:1}

1. Implikasi hukum terhadap pembagian waris 2:1,

Syariat dan ketentuan Allah SWT dalam al-Qur'an surat an-Nisa' :11,12,176 menjelaskan porsi masing-masing ahli waris, kemudian Allah menegaskan dalam ayat 13 dan 14 bahwa ketentuan tentang porsi masing-masing ahli waris tersebut merupakan hukum dan ketetapan Allah SWT. sebagaimana arti ayat berikut:

(Hukum-hukum tersebut) itu adalah ketentuan-ketentuan dari Allah. barangsiapa taat kepada Allah dan Rasul-Nya, niscaya Allah memasukkannya kedalam syurga yang mengalir didalamnya sungai-sungai, sedang mereka kekal di dalamnya; dan Itulah kemenangan yang besar.(QS. An-Nisa':13).

Dan barangsiapa yang mendurhakai Allah dan rasul-Nya dan melanggar ketentuan-ketentuan-Nya, niscaya Allah memasukkannya ke dalam api neraka sedang ia kekal di dalamnya; dan baginya siksa yang menghinakan.(QS. An-Nisa': 14).

Ketentuan-ketentuan hukum yang digariskan oleh Allah untuk mengatur tata tertib kehidupan manusia bertujun untuk mewujudkan kebahagiaan manusia di dunia dan di akhirat. Di antara ketentuan hukum itu ada yang mengandung sanksi dan ada yang menuntut supaya dipatuhi saja untuk mencapai suatu kemaslahatan. Kerena itu, hukumhukum Allah itu ada yang bersifat mengatur (regelent recht) dan ada hukum yang bersifat memaksa (dwingend recht). ${ }^{44}$

Ketentuan hukum yang bersifat mengatur (regelent recht) merupakan anjuran yang sangat daripada Allah untuk

${ }^{44}$ H.M. Anshary MK, Hukum Kewarisan Islam dalam Teori dan Praktik, (Yogyakarta: Pustaka Pelajar, 2013), hlm. 66.

Sangaji Jurnal Pemikiran Syariah dan Hukum 
dipatuhi dalam rangka menciptakan keseimbangan dan keharmonisan pergaulan hidup di dunia serta untuk mencapai kemaslahatan di hidup di akhirat. Oleh karena itu, terhadap suatu perbuatan yang tidak ada alternatif lain yang menguntungkan semua pihak, maka pilihan terakhir kembali kepada ketentuan yang telah diatur oleh Allah SWT. Sedangkan suatu ketentuan hukum yang bersifat memaksa (dwingend recht) merupakan pilihan yang tunggal yang wajib di patuhi, dan para pelanggarnya akan mendapatkan sanksi dari Allah SWT.

Pembagian waris 2:1 telah diatur dalam al-Qur'an secara jelas dan terperinci maupun dalam Kompilasi Hukum Islam (KHI) pasal 176 "Anak perempuan bila hanya seorang ia mendapat separuh bagian, bila dua orang atau lebih mereka bersama-sama mendapat dua pertiga bagian, dan apabila anak perempuan bersama-sama dengan anak laki-laki, maka bagian anak laki-laki adalah dua berbanding satu dengan anak perempuan." 45 Oleh karena telah diatur dalam al-Qur'an maupun Undangundang, sehingga memiliki kekuatan hukum. Apabila terjadi pembagian waris di luar dari ketentuan hukum dan terjadi perselisihan dikemudian hari.

2. Implikasi terhadap keadilan berimbang,

Konsepsi manusia dalam Islam adalah didasarkan pada tugas-kewajiban. Al-Qur'an menekankan bahwa tanggung jawab manusia bersifat individual dan bahwa Islam menjujung tinggi manusia sebagai norma pokok.

Dalam problemmatika hukum pembagian waris 2:1 kalau dikaji dengan pendekatan keadilan berimbang. Muncul pertanyaan, mengapa bagian kaum laki-laki dua kali lipat bagian kaum wanita, padahal kaum wanita jauh lebih banyak

${ }^{45}$ Lihat Undang-Undang RI No. 1 Tahun 1974, Tentang Perkawinan dan Kompilasi Hukum Islam, (Bandung: Cintra Umbara, 2012), hlm. 377. 
membutuhkannya, karena di samping memang lemah, mereka juga sangat membutuhkan bantuan baik moril maupun materil?

Untuk menjawab pertanyaan tersebut perlu saya utarakan beberapa hikmah adanya syariat yang telah Allah tetapkan bagi kaum muslim, di antaranya sebagai berikut:

a. Perempuan selalu harus terpenuhi kebutuhan dan keperluannya, dan dalam hal nafkahnya kaum wanita wajib diberi oleh ayahnya, saudara laki-lakinya, anaknya, atau siapa saja yang mampu di antara kaum laki-laki kerabatnya. Sebagaimana disebutkan dalam HR. Muslim no. 1218.

b. Perempuan tidak diwajibkan untuk memberi nafkah kepada siapapun. Sebaliknya, kaum lelakilah yang mempunyai kewajiban untuk memberi nafkah kepada keluarga dan kerabatnya, serta siapa saja yang diwajibkan atasnya untuk memberi nafkah dari kerabatnya. Sebagaimana yang dijelaskan dalam QS. Al-Baqarah ayat 233.

c. Nafkah (pengeluaran) laki-laki jauh lebih besar dibandingkan kaum wanita. Dengan demikian, kebutuhan kaum laki-laki untuk mendapatkan dan memiliki harta jauh lebih besar dan banyak dibandingkan kaum wanita.

d. Laki-laki diwajibkan untuk membayar mahar kepada istrinya, menyediakan tempat tinggal baginya, memberikan makan, minum, dan sandang. Dan ketika telah dikaruniai anak, ia berkewajiban untuk memberikan sandang, pangan, dan papan. Dijelaskan dalam QS. AnNisa' ayat 4 .

e. Kebutuhan pendidikan anak, pengobatan jika anak sakit (termasuk istri) dan lainnya, seluruhnya dibebankan hanya pada pundak kaum laki-laki. Sementara perempuan 
tidaklah demikian. Sebagaimana dijelaskan dalam HR. Bukhari no. 5364.

Demikian beberapa hikmah dari sekian banyak hikmah yang terkandung dalam perbedaan pembagian antara kaum laki-laki dua kali lebih besar dari kaum wanita. Secara logika, siapa pun yang memiliki tanggung jawab besar, hingga harus mengeluarkan penbiayaan lebih banyak, maka dialah yang lebih berhak untuk mendapatkan bagian yang lebih besar pula. Inilah yang dimaksud dengan kaadilan berimbang, seimbang antara hak yang didapat dengan beban dan kewajiban yang diembannya.

Pengertian adanya keseimbangan antara hak harta waris yang diperoleh dengan kewajiban atau beban kehidupan yang harus ditanggungnya atau ditunaikannya di antara para ahli waris. Oleh karena itu, arti keadilan dalam hukum waris Islam bukan diukur dari kesamaan tingkatan antara ahli waris, tetapi ditentukan berdasarkan besar-kecilnya beban atau tanggung jawab diembankan kepada mereka, ditinjau dari keumuman keadaan/kehidupan manusia.

Dalam Tafsìr Fì Dzilālil Qur'an, sebagaimana yang dikutip oleh Lutfi Hakim menerangkan bahwa masalah 2:1 bagi laki-laki dan perempuan merupakan sebuah keadilan dikarenakan kewajiban laki-laki dinilai lebih berat daripada kewajiban seorang perempuan, seperti pembayaran mas kawin ataupun masalah penafkahan keluarga. Penetapan keadilan menunjukkan keseimbangan dengan dasar berbedanya tanggung jawab antara laki-laki dengan perempuan. Jika dikaitkan dengan definisi keadilan yang dikemukakan Amir Syarifuddin "Keseimbangan antara hak dan kewajiban dan keseimbangan antara yang diperoleh dengan keperluan dan kegunaan", atau perimbangan antara beban dan tanggung jawab di antara ahli waris yang sederajat, maka kita 
akan melihat bahwa keadilan akan nampak pada pelaksanaan pembagian harta warisan menurut Islam. ${ }^{46}$

\section{Simpulan}

Hukum pembagian kewarisan Islam formula 2:1 adalah bersifat qath"i. Sebagaimana telah dijelaskan oleh Allah dalam alQur'an surat an-Nisa': 11,12 dan 176 dengan tegas, pasti, dan jelas rincian pembagiannya sehingga tidak perlu lagi diijtihad. Artinya, bahwa setiap ahli waris harus meyetujui porsi yang telah ditetapkan oleh Allah SWT tersebut, tanpa harus mencari argumentasi pembenar untuk mengugat berlakunya ketentuan ayat tersebut. Inilah hakikatnya mengapa Allah SWT menegaskan pada ujung ayat 11 dengan kalimat فريضة من اله فئ artinya: “ini adalah ketetapan Allah", dan Allah juga menegaskan pada ujung ayat 176 dengan kalimat ييين اله لكم أن تضلو او الله بكل شيء عليم yang artinya: "Allah menerangkan (hukum ini) kepadamu, agar kamu tidak sesat, Allah Maha Mengetahui segala sesuatu." Kemudian dalam QS. An-Nisa' ayat 13 dan 14 Allah SWT menegaskan lagi bahwa garis-garis hukum itu adalah ketentuan daripada Allah, barang siapa yang tidak mematuhinya akan mendapat sanksi dari Allah SWT.

Namun demikian, apabila ahli waris sepakat untuk menyelesaikan pembagian harta waris dengan suatu kesepakatan yang berbeda dengan ketentuan ayat tersebut, dengan suatu ketentuan bahwa semua ahli waris benar-benar mengetahui akan porsi dan haknya masing-masing, maka sepanjang pembagian yang disepakati itu tidak merugikan ahli waris yang lain, pembagian semacam itu dibenarkan. Ketentuan tersebut juga diatur dalam pasal $183 \mathrm{KHI}$ yang berbunyi: "para ahli dapat

${ }^{46}$ M. Lutfi Hakim, "Keadilan Kewarisan Islam Terhadap Pembagian Waris 2:1 antara Laki-Laki dan Perempuan Perspektif Filsafat Hukum Islam", dalam Jurnal Hukum Islam, STIS Syarif Abdurrahman Pontianak. Vol. VII No. I, Januari 2011, hlm. 26.

Sangaji Jurnal Pemikiran Syariah dan Hukum 
bersepakat melakukan perdamaian dalam pembagian harta warisan, setelah masing-masing menyadari bagiannya". Tetapi sebaliknya, jika tidak ada kesepakatan tersebut, maka hukum yang terdapat dalam surat an-Nisa' ayat 11, 12, dan 176 tersebut bersifat memaksa (dwingend recht) atau bersifat qath'i.

\section{DAFTAR PUSTAKA}

Abu Zahrah, Muhammad. Ushul Figh, Jakarta: Pustaka Firdaus,1994.

al-Qurthubi, Imam. Tafsir al-Qurthubi, terj. Ahmad Rijal Kadir, Jidil ke-5, Jakarta: Pustaka Azzam, 2008.

al-Zuhaily, Wahbah. Ushul Fikih al-Islami, Beirut: Dar al-Fikr, 2001.

al-Syatibi. al-Muwafaqat, jilid III. Cairo: Dar al-Fikr,t,t.

Anshary, Muhammad. Hukum Kewarisan Islam dalam Teori dan Praktik, Yogyakarta: Pustaka Pelajar, 2013.

Asrizal. "Peletakan Dasar-dasar Hukum Kewarisan Islam (Tinjau Historis atas Hukum Waris Pra dan Awal Islam)," dalam al-Ahwal Jurnal Hukum Keluarga Islam, Fakultas Syari'ah dan Hukum UIN Sunan Kalijaga, Vol 9, No.1, Juni 2016.

Djamil, Fathurrahman. Filsafat Hukum Islam, Jakarta: Logos Wacana Ilmu, 1997.

Fanani, Muhyar. “Sejarah Perkembangan Konsep Qath'i-Zhanni Perbedaan Ulama Tentang Anggapan Kepastian dan Ketidakpastian Dalil Syari'at," dalam Jurnal Al-Jami'ah, UIN Sunan Kalijaga, Vol. 39, No. 2 Juli 2001.

Farid Mas'ud, Mashdar. Hak-hak Reproduksi Perempuan: Dialog Fiqh Pemberdayaan, Bandung: Mizan, 1997.

Ghofur Anshori, Abdul. Hukum Kewarisn Islam di Indonesia. Yogyakarta: EKONISIA (Kampus Fakultas Ekonomi) UII, 2005.

Hazairin, Filsafat Hukum Kewarisan Islam, Konsep Kewarisan Bilateral, Yogyakarta: UII Press, 2010. 
Hakim, Lutfi "Keadilan Kewarisan Islam Terhadap Pembagian Waris 2:1 antara Laki-Laki dan Perempuan Perspektif Filsafat Hukum Islam", dalam Jurnal Hukum Islam. STIS Syarif Abdurrahman Pontianak. Vol. VII No. I, Januari 2011.

Haroen, Nasrun, Ushul Fiqh, Jakarta: Logos, 1996.

Hashim Komali, Muhammad. Principles of Islamic Jurisprudence, Diterjemahkan oleh Noorhaidi dengan judul: "Prinsip dan Teori-Teori Hukum Islam, Yogyakarta: Pustaka Pelajar, 1996.

Kementerian Agama, al-Qur'an dan Terjemahannya, Bogor: Sygma Examedia Arkanleeme, 2007.

Muhammad, Teungku Hasbi Ash-Shiddieqy. Fiqh Mawaris,

Hukum Pembagian Warisan Menurut Syariat Islam, Semarang: Pustaka Rizki Putra,2017.

Muhammad, Abu Ja'far bin Jarir Ath-Thabi. Tafsir Ath-Thabari, terj. Akhmad Affandi, Jilid ke-6, Jakarta: Pustaka Azzam, 2008.

Quraish Shihab, Muhammad. Membumikan al-Qur'an, Bandung: Mizan,1994.

. Tafsir al-Mishbah, Jilid ke-2, Jakarta: Lenteran Hati, 2016.

- Membumikan al-Qur'an, Fungsi dan Peran Wahyu dalam Kehidupan Masyarakat, Bandung: Mizan, 1999.

Rasyid Ridha, Muhammad. Tafsir al-Manar, Cairo: al-Manar,1367 $\mathrm{H}$.

Sajdzali, Munawir. Reaktualisasi Ajaran Islam, dalam Polemik Reaktualisasi Ajaran Islam, Jakarta: Pustaka Panjimas, 1988.z

Saleh dan Dahlan. Asbabun Nuzul, Latar Belakang Historis Turunnya Ayat-ayat al-Qur'an, cet. ke-10, Bandung: Diponegoro, 2000.

Sangaji Jurnal Pemikiran Syariah dan Hukum 
Syaikh Ahmad Syakir. Mukhtashar Tafsir Imam Ibnu Katsir, Jilid ke-2, terj. Suharla dan Suratman, Jakarta: Darus Sunnah, 2014.

Usman, Suparman dan Yusuf Somawinata. "Fiqh Mawaris", dalam Hukum Kewarisan Islam, Jakarta: Gaya Media Pratama, 2002.

Wahhab Khallaf, Abdul. Ilmu Ushul Fiqh. Dar al-Kuwaitiyyah, cek. Ke-8, 1968

Yahya, Muktar dan Facthurahman. Dasar-dasar Pembinaan Hukum Fiqih Islami, Bandung: al-Ma'arif, 1993. 